\title{
TEORIA DA CONJUNTURA: UM DEBATE A PARTIR DOS GOVERNOS LULA
}

\author{
Conjecture Theory: a discussion from the Lula governments
}

Pedro Felipe Narciso'

\begin{abstract}
Resumo
Neste artigo pretendemos observar de modo criterioso quatro das principais análises de conjuntura que versam sobre o período em que Lula da Silva foi Presidente do Brasil, são elas: a) a análise do governo pós-neoliberal, b) a análise do governo de conciliação de classes, c) a análise do governo de arbitragem e d) a análise do governo da frente neodesenvolvimentista. Vale salientar que nosso objeto não são as análises em si, mas os sistemas teóricos que as sustentam, nesse sentido defendemos duas hipóteses complementares: primeiro, as três primeiras análises carregam consigo pelo menos uma inconsistência, ou o fetichismo de Estado ou o economicismo-voluntarista; e, segundo, a última análise citada supera essas deficiências por meio das teorias da conjuntura, do bloco no poder e das frações burguesas que aparecem ali em estado aplicado. Considerando que nosso objetivo é contribuir com a sistematização de uma teoria da análise de conjuntura buscamos evidenciar uma definição do conceito de conjuntura, os seus elementos constitutivos fundamentais e sua diferenciação em dois tipos básicos.
\end{abstract}

Palavras-chave: Teoria da conjuntura; Fetichismo de Estado; Neodesenvolvimentismo; Governo Lula.

\begin{abstract}
In this article we intend to carefully observe four of the main conjuncture analyzes that deal with the period in which Lula da Silva was President of Brazil, they are: a) the post-neoliberal government analysis, b) the classes conciliation government's analysis, c) the analysis of the government of arbitration and d) the analysis of the government of the neodevelopmental front. It is worth noting that our object is not the analyzes themselves, but the theoretical systems that support them. In this sense, we defend two complementary hypotheses: first, the first three analyzes carry at least one inconsistency, or State fetishism or voluntarist economism; and, second, the last analysis cited overcomes these deficiencies through the theories of the conjuncture, the bloc in power and the bourgeois fractions that appear there in an applied state. Considering that our objective is to contribute to the systematization of a theory of the analysis of the conjuncture, we seek to highlight a definition of the concept of the conjuncture, its fundamental constituent elements and its differentiation into two basic types.
\end{abstract}

Keywords: Conjuncture theory; State fetishism; Neodevelopmentism; Lula government.

${ }^{1}$ Mestre em Sociologia pela Universidade Federal de Pelotas (UFPel). Doutorando em Ciência Política na Universidade Estadual de Campinas (UNICAMP). E-mail: pedro_felipenarciso@hotmail.com 


\section{Introdução}

O presente artigo tem o objetivo de tecer algumas considerações sobre a teoria da análise de conjuntura a partir de um caso concreto, delineando, assim, alguns dos principais elementos conceituais que subjazem as diferentes análises. O caso concreto que enseja o debate teórico ora proposto se refere aos governos encabeçados por Luís Ignácio Lula da Silva ou, mais especificamente, sobre a sua correta caracterização. O cumprimento do objetivo supracitado passa pela realização de dois objetivos parciais, primeiro o de apresentar um panorama crítico das considerações produzidas pela academia brasileira sobre o período dos referidos governos; e, segundo, o de oferecer alternativas conceituais capazes de superar aquelas limitações.

No que se refere à estrutura expositiva o artigo está organizado em três seções. Na primeira, as análises correntes e seus limites, pretende-se apresentar um panorama geral das leituras estabelecidas e suas principais insuficiências. Na seção seguinte, alternativas teóricas para a análise de conjuntura, busca-se oferecer de modo justificado um instrumental teórico que dê conta dos aspectos críticos anteriormente observados. Em teoria aplicada e o Brasil neodesenvolvimentista - a seção terceira - expõe-se a aplicação do arcabouço conceitual previamente apresentado à conjuntura em questão, ou seja, a teoria em seu estado prático.

\section{As análises correntes e seus limites}

Nesta seção, como antecipado na introdução, pretende-se oferecer um panorama de algumas das principais caracterizações acerca dos governos Lula, em especial o segundo governo, período no qual a era petista no comando do Executivo Federal conheceu o seu auge. As perspectivas observadas são as seguintes: a hipótese pós-neoliberal, a hipótese da conciliação de classes (nas suas diferentes versões) e a hipótese do governo de arbitragem.

A primeira das caracterizações, a de governo pós-neoliberal, tem como principal formulador o cientista político Emir Sader (2013), para quem os governos encabeçados por Lula compõem um amplo processo continental de reação ao neoliberalismo. Tal processo constituir-se-ia pela ascensão dos Kirchner na Argentina, de Chávez na Venezuela, de Evo Morales na Bolívia, de Rafael Correa no Equador e da Frente Ampla no Uruguai. Os governos 
acima mencionados poderiam ser todos caracterizados como pós-neoliberais, pois, entre outras características, priorizariam "as politicas sociais e não o ajuste fiscal", "os processos de integração regional e os intercâmbios Sul-Sul e não os tratados de livre-comércio com os Estados Unidos" e "o papel do Estado como indutor do crescimento econômico e da distribuição de renda, em vez do Estado mínimo e da centralidade do mercado" (SADER, 2013, p. 138).

Considerando então o governo de Lula como parte de um fenômeno continental de reação ao neoliberalismo, o autor entende a realização do pósneoliberalismo brasileiro como consequência "da intuição e do pragmatismo de Lula como presidente" (SADER, 2013, p. 139) que combinou as politicas voltadas à estabilização monetária com a indução do desenvolvimento econômico e a distribuição de renda. De acordo com Sader a astúcia pragmática de Lula conseguiu estabelecer uma ampla hegemonia pósneoliberal assegurada pelo apoio popular manifesto no pleito da reeleição presidencial em 2006, o que robusteceu as aspirações pós-neoliberais consubstanciadas "pela decisão do governo de priorizar as políticas sociais e a reinserção internacional do Brasil” (SADER, 2013, p. 141).

A hipótese do professor Sader traz pelo menos dois elementos apropriados. Primeiro, o autor reconhece que, embora aspectos importantes da política macroeconômica tenham se mantido, os governos Lula não representam uma simples continuidade em relação aos governos Fernando Henrique Cardoso (1995-2003). O segundo elemento que merece ser destacado como correto na apreciação da hipótese pós-neoliberal é a relação diferenciada que Lula manteve com os outros países da América do Sul, cujos governos também representavam uma novidade politica em seus respectivos países e, portanto, poderiam ser agrupados como elementos de um processo continental.

Embora seja possivel destacar tais méritos na leitura de Sader, esses são ofuscados quando articulados com o conjunto de proposições que fundamentam a proposta do autor. Em primeiro lugar, Sader desconsidera a complexidade e a diversidade existente entre os chamados governos pósneoliberais, tais como as diferenças entre as conjunturas internas, as diferenças de composição social que ensejaram cada uma das vitórias 
eleitorais, as diferenças entre os tipos de oposição que enfrentavam e aquilo que vislumbravam como programa político e econômico.

Uma análise mais matizada sobre os governos que Sader classifica como pós-neoliberais pode ser verificada, por exemplo, na obra Neoliberalismo, Neodesenvolvimentismo e Socialismo, do economista argentino Cláudio Katz (2016). Nela o autor desenvolve uma argumentação detalhada sobre os governos da região e sobre as diferentes possibilidades de conceituá-los, desde as experiências neodesenvolvimentistas, como Argentina e Brasil; até aquelas consideradas como sendo social-desenvolvimentismo com imaginário socialista, como os casos do Socialismo do Século XXI, na Venezuela, e do Socialismo Comunitário, na Bolivia.

A outra crítica que pode ser feita a Sader refere-se às movimentações politicas dos grandes agrupamentos sociais que o autor ignora, tais como as classes, sobretudo aquelas que desempenham funções politicas dominantes. Ao reduzir os processos de construção de hegemonia às habilidades pragmáticas de um lider e a sua capacidade de obter sucesso eleitoral, o autor encobre a dinâmica subjacente dos processos eleitorais, tomando, assim, os embates da cena política como a única política existente. Desse modo, as proposições que o autor defende são incapazes de observar que a chancela popular das urnas corresponde ao momento do consenso ampliado, àquele que diz respeito à hegemonia ideológica perante as massas, eleitorais no caso do fenômeno Lula. No entanto, mais do que isso, é necessário observar também os processos de hegemonia politica no interior do bloco no poder, o que, pelo próprio desenvolvimento dos acontecimentos políticos, tem se demonstrado como sendo o fator verdadeiramente decisivo. Portanto, mais do que uma teoria precisa sobre o caráter dos governos Lula, a concepção de Sader manifesta-se como um exemplo patente de fetichismo do Estado ${ }^{2}$ (BOITO Jr, 2018), em que esse é entendido como uma instituição livre e

\footnotetext{
2 O conceito de fetichismo de Estado aparece também em Pierre Bourdieu, no entanto, nesse autor o conceito tem uma acepção diferente. O sociólogo francês mobiliza o termo fetichismo de Estado para caracterizar o processo de formação dos Estados-nacionais modernos que, de acordo com ele, foram produzidos pelas elites jurídicas instaladas nos centros burocráticos, as quais forjaram uma unidade linguística e cultural de povos e comunidades que habitavam um território determinado, assegurando, assim, a legitimação do poder de Estado. A tese do autor busca contrariar a perspectiva, muito difundida, de que o Estado é produto de uma unidade cultural ancestral e espontânea (BOURDIEU, 2014).
} 
soberana da qual emana o poder político e cujo acesso é possibilitado exclusivamente pela conquista periódica do sufrágio popular.

A segunda hipótese a ser aqui apresentada é a que caracteriza os governos Lula como um governo de conciliação de classes. Tal hipótese se divide em pelo menos dois grandes grupos de autores, os inspirados na tradição teórica que remonta os escritos de Leon Trotsky e aqueles que fundamentam suas concepções no arcabouço teórico que se desenvolve a partir das contribuições teóricas de Antônio Gramsci.

Os autores trotskistas da tese da conciliação, tal qual Sader, destacam a importância das determinações externas para a explicação do fenômeno dos governos Lula. No entanto, ao contrário de Sader, aqueles entendem a ascensão de Lula como uma reação ao processo regional ${ }^{3}$ de radicalização antineoliberal e não como um desdobramento nacional daquele processo.

De acordo com Valério Arcary $(2008 ;$ 2013) o Partido dos Trabalhadores foi, ao longo dos anos de 1990, progressivamente incorporado como oposição oficial desejável pela classe dominante, pois, como variante mais moderada das esquerdas diversas o partido cumpria um papel de desmobilização popular na medida em que consolidava sua hegemonia naquele campo do espectro político. Para o autor, essa posição conquistada pelo Partido dos Trabalhadores foi fundamental para que ao fim da década de 1990 o Brasil - ao contrário de Equador, Argentina, Venezuela e Bolívia pudesse reformar o neoliberalismo de modo pacífico, pela via institucional e sem enfrentar um contexto interno de crise revolucionária.

Na mesma linha de Arcary, Osvaldo Coggiola (2013) reforça a hipótese da conciliação destacando, respectivamente, a crise do segundo governo FHC, a ascensão eleitoral do Partido dos Trabalhadores nos pleitos municipais de 2000 e a situação revolucionária dos países vizinhos como indicadores que sinalizavam à burguesia a necessidade de uma nova estratégia de dominação, no caso, o estabelecimento de uma estratégia de conciliação de classe, designado na tradição trotskista pela categoria de governo de frente popular. Para o autor, a crise argentina de 2001 acelerou esse processo fazendo com que o empresariado brasileiro se aproximasse da candidatura petista. $\mathrm{O}$

3 O termo regional designa o subcontinente latino-americano. 
compromisso com o imperialismo foi selado com o aval do então candidato Lula ao pacote de empréstimos oferecidos pelo FMI em setembro de 2002, fazendo, assim, que o FMI estabelecesse "de fato as bases do programa de governo para os quatro anos de mandato do PT" (COGGIOLA, 2013, p. 13).

A tese trotskista da conciliação assevera, em suma, que o PT burocratizou e apassivou o conjunto dos movimentos populares e sociais, sobretudo o movimento sindical, garantindo a estabilidade do regime político num momento de crise e desgaste das políticas neoliberais mais radicais, proporcionando-lhes uma sobrevida. Isso teria sido possivel pelo alinhamento de Lula ao imperialismo estadunidense, pois Lula teria servido como "interlocutor do governo norte-americano para os governos venezuelano, boliviano e equatoriano" constituindo-se, assim, como uma "influência moderadora sobre Chávez, Evo Morales e Correa” (ARCARY, 2013, p. 4).

A leitura trotskista sobre o caráter dos governos Lula avança em relação à leitura pós-neoliberal quando observa a complexidade dos processos de ascensão de novos governos na América Latina entre o final dos anos de 1990 e o começo dos anos 2000. Entretanto, as suas duas hipóteses basilares não se confirmam à luz dos acontecimentos observados, seja sobre o alinhamento automático de Lula com a política estadunidense para a América Latina; ou sobre o caráter absolutamente desmobilizador dos governos Lula sobre a classe trabalhadora.

Sobre a primeira hipótese adverte-se que as pesquisas têm indicado justamente o contrário, pois, uma das marcas mais importantes do Brasil de Lula foi a alteração do padrão de "submissão passiva" frente ao imperialismo norte-americano para uma posição de "subordinação conflitiva" (BERRINGER, 2014). Essa nova postura pode ser observada, entre outras medidas, pela desativação do projeto Área de Livre Comércio das Américas (ALCA), pela priorização de políticas de integração regional com a América Latina, pela criação do Fundo dos BRICS ${ }^{4}$ e pelo estreitamento das relações com esses países (tanto os da América Latina quanto os membros dos BRICS). Todas essas medidas, antes de representarem a intervenção terceirizada de Washington na América Latina moderando ou desestabilizando as novas

\footnotetext{
${ }^{4}$ A sigla BRICS refere-se ao bloco de cooperação econômica constituído por Brasil, Rússia, Índia, China e África do Sul.
} 
experiências de governo, acabaram, na verdade, fortalecendo e garantindo maior estabilidade às experiências dos governos de Hugo Chávez, na Venezuela; de Néstor e Cristina Kirchner, na Argentina; de Evo Morales, na Bolivia; e de Rafael Correa, no Equador.

Sobre a última hipótese, salienta-se que, embora as cúpulas sindicais possam ter moderado as suas bandeiras politicas mais gerais, o movimento sindical como um todo avançou em suas conquistas reivindicativas tendo "logrado aumentos salariais e ampliação de benefícios na grande maioria dos acordos coletivos graças às greves por categorias" (BOITO Jr, 2018, p. 205), ao contrário do que ocorria na década anterior quando a maior parte das greves tinha um caráter meramente defensivo, ou seja, contra a retirada de direitos e beneficios. Dessa maneira, a tese do apassivamento pode ser considerada como imprecisa, pois o período Lula demonstrou-se como sendo mais favorável às conquistas do movimento sindical do que o período dos governos que o antecederam.

Dentre todas as vertentes e tradições teóricas expostas, aquela cujas análises remetem aos conceitos de Antônio Gramsci é, muito provavelmente, a que comporta maior variedade de versões. Dessa maneira, inexistindo uma versão que contemple a diversidade das análises no interior da vertente gramsciana, optou-se por apresentar as três principais variantes dessa versão da tese da conciliação de classes, que são as seguintes: a tese da hegemonia às avessas, de Francisco de Oliveira; a tese da revolução passiva à brasileira, de Ruy Braga; e a tese da hegemonia da pequena politica, de Carlos Nelson Coutinho.

A leitura de Francisco de Oliveira (2010) é bastante simples e direta, embora, pretenda-se, com razão, inovadora, pois, inverte uma relação conceitual clássica. Para o autor, Lula e o PT, ambos com origem nas classes populares, ao chegarem ao executivo federal optaram por transmitir a falsa ideia de que todos os privilégios de classe teriam sido abolidos. Dessa maneira, a questão social brasileira teria sido despolitizada pelo presidente operário, ganhando um status meramente administrativo. Portanto, agora, poderia ser superada pela aplicação correta de recursos em políticas públicas eficientes. Nas palavras de Oliveira, 
Chegando ao poder, o PT e Lula criaram o Bolsa Família, que é uma espécie de derrota do apartheid. Mais ainda: ao elegermos Lula, parecia ter sido borrado para sempre o preconceito de classe e destruídas as barreiras da desigualdade. Ao elevar-se à condição de condottiere e de mito, como as recentes eleições parecem comprovar, Lula despolitiza a questão da pobreza e da desigualdade. Ele as transforma em problemas de administração, derrota o suposto representante das burguesias - o PSDB, o que é inteiramente falso - e funcionaliza a pobreza. Esta, assim, poderia ser trabalhada no capitalismo contemporâneo como uma questão administrativa (OLIVEIRA, 2010, p. 24-25).

Nesse sentido, ostentando a insignia de representante do povo, Lula teria conseguido amarrar em torno de si um grande acordo entre dominantes e dominados. Desse modo, as cúpulas sindicais, pactuadas com o grande capital, exerceriam a "direção moral" da sociedade com a condição de não avançar sobre os interesses da exploração capitalista. É nesse sentido que o processo de hegemonia se inverte, pois "não são mais os dominados que consentem em sua própria exploração; são os dominantes - os capitalistas e o capital, explicite-se - que consentem em ser politicamente conduzidos pelos dominados" (OLIVEIRA, 2010, p. 27), pois essa seria uma condição sine qua non para que o programa neoliberal dos governos FHC pudesse ser mantido nos marcos da estabilidade política e institucional.

Radicalizando a análise de Francisco de Oliveira, Ruy Braga apresenta a hipótese da revolução passiva à brasileira, na qual os governos Lula não cumpririam apenas um papel de apassivador passivo diante dos desajustes do neoliberalismo brasileiro, mas cumpririam também um papel importante no sentido de possibilitar uma radicalização neoliberal, executando um programa de reformas e transformações que os governos anteriores foram incapazes de aplicar devido a sua incapacidade de organizar o consenso. Ruy Braga $(2010 ; 2012)$, partindo de um estofo teórico regulacionista, defende que durante a transição democrática o Brasil transitou, com ênfase nos anos de 1990, de um regime de acumulação despótico com características fordistas para um regime de acumulação pós-fordista periférico marcado pela "terceirização empresarial, a privatização neoliberal e a financeirização do trabalho" (BRAGA, 2012, p. 27). Essa mudança de regime de acumulação não foi acompanhada por um modo de regulação com condições de consolidar a 
transição ao novo regime e garantir a sua reprodução, o que lhe conferia uma alta carga de instabilidade.

O conceito de revolução passiva - caracterizada como uma revoluçãorestauração em que prevalece o momento da restauração - seria preciso, de acordo com Braga, para caracterizar os governos Lula, pois esses expressariam uma transição para um novo modo de regulação que fosse capaz de assegurar a conservação do regime de acumulação vigente, o pós-fordismo periférico. Esse novo modo de regulação consistiria em organizar o consentimento ativo das cúpulas sindicais e o consentimento passivo das grandes massas não sindicalizadas e precarizadas. O primeiro tipo de consentimento organizar-se-ia pela incorporação dos dirigentes sindicais aos aparelhos de Estado e pela expansão da administração sindical dos fundos de pensão; enquanto o consentimento passivo, por sua vez, seria alcançado por medidas como o

Bolsa Família, a ampliação do sistema universitário federal com o patrocínio das cotas, o impulso na direção da "reformalização" do mercado de trabalho, a política de reajuste do salário mínimo acima da inflação, a retomada dos investimentos em infraestrutura ou, mais recentemente, o incentivo ao consumo de massas por meio do crédito consignado (BRAGA, 2010, p. 13).

Contrário à hipótese da revolução passiva à brasileira, Carlos Nelson Coutinho (2010), em "Hegemonia da pequena política", considera que não existe uma incorporação significativa das pressões "dos de baixo" que oriente a classe dominante num caminho de inovação política capaz de estabelecer condições para outras mudanças, o que ele considera o âmago do conceito esboçado por Gramsci. Discordando então da hipótese da revolução passiva, Coutinho aposta na tese do fenômeno Lula como expressão de hegemonia da pequena política. Ou seja, quando a visão de mundo de uma classe, no caso a burguesia, é incorporada pelo senso-comum como uma natureza inevitável. Nesse caso, a disputa entre visões amplas - projetos sociais completos, valores de fundo - é ignorada pelo debate político, sendo esse hegemonizado pelas diferentes maneiras, cada vez mais estreitas, de "administração do existente" (COUTINHO, 2010, p. 32).

O governo Lula, hegemonizado pela visão de mundo burguesa, seria um governo que procederia somente pela pequena politica e, portanto, não 
poderia ser agente de uma revolução passiva, tal como no exemplo paradigmático do Risorgimento, em que as classes do velho regime em decomposição incorporam os valores das classes em ascensão no sentido de reproduzir-se como classes dominantes na sociedade nova que emerge. Para Coutinho, no período Lula não há luta entre valores ou entre visões de mundo, não há nova sociedade à vista, mas, pelo contrário, um processo em que o momento do novo está totalmente submetido pelo momento da restauração. Nesse sentido, Carlos Nelson Coutinho recupera o conceito de contrarreforma para caracterizar o governo Lula, pois, as politicas de tal governo representariam, na verdade, um processo de reabilitação do liberalismo clássico que antecedeu as concessões observadas pelo período do fordismo e do Estado de Bem-Estar, período no qual se observou, de acordo com o autor, uma autêntica Revolução Passiva.

Concluída a exposição das diferentes versões da compreensão gramsciana sobre o período Lula, cabe destacar agora os pontos mais frágeis de cada uma delas. Seguindo a ordem de aparecimento de cada uma das variantes, destaca-se, primeiramente, que a versão da hegemonia às avessas, defendida por Francisco de Oliveira, incorre em dois equivocos principais. Primeiro, o autor aposta, tal como a versão trotskista, numa continuidade da política dos governos Lula em relação ao período FHC, o que já se mostrou, em argumentação anterior, como sendo problemático. O segundo ponto a ser destacado refere-se ao tratamento do fenômeno de ocupação do Estado por lideranças oriundas do movimento sindical e popular como algo quase inédito, comparável somente ao que teria ocorrido na África do Sul pós-apartheid. Embora a inversão das funções desempenhadas pelos termos dominaçãoconsentimento seja, de fato, aparentemente nova em termos puramente conceituais, ao contrário do que preconiza Oliveira, o fenômeno e a problemática da disjunção entre classes que dominam e classes que governam não é recente no debate sobre o Estado capitalista. Já "em 1902, Karl Kautsky observava que a classe capitalista domina, mas não governa” (MILIBAND, 1972, p. 74). Desde então, diferentes pesquisadores realizaram importantes desenvolvimentos teóricos sobre o referido fenômeno, de tal forma que, inclusive, pondera-se que o mesmo não constitui uma anomalia, mas uma característica estrutural do Estado Capitalista, um tipo de Estado 
caracterizado por ser formalmente aberto à participação de membros oriundos de todas as classes (SAES, 1993; 1985; BOITO Jr, 2007; MARTUSCELLI, 2018; POULANTZAS, 1977).

No que tange à análise regulacionista, de Ruy Braga, essa peca pelo excesso de formalismo, que tem como consequência a desconsideração de disputas políticas mais complexas, tanto no que se refere à manifestação do capital e do trabalho em categoriais mais ricas em determinações, as de capitalistas e de trabalhadores, que não são reflexos unívocos do capital em geral e do trabalho em geral e, portanto, não são reféns de sua posição econômica; quanto de outras cadeias de contradições que se agrupam e transcendem esse padrão de relação. Braga estabelece um padrão de reprodução da relação capital e trabalho e deriva disso às regulações necessárias capazes de reproduzi-lo, como se o estabelecimento de um modo de regulação fosse consequência lógica, necessária e inexorável de um regime de acumulação. Nessa perspectiva a análise das movimentações concretas das classes e das frações de classe quase que desaparece, restando somente as necessidades de manutenção fatalista do padrão econômico formal.

$\mathrm{Na}$ terceira versão da conciliação de classes, Coutinho faz uma observação interessante sobre a hegemonia da pequena politica nos governos Lula, mas essa não consegue transpassar os limites de uma observação meramente descritiva. Carlos Nelson Coutinho trata a hegemonia dos assuntos administrativos como se fosse uma opção voluntária e superestrutural das direções, excessivamente integradas à máquina pública e sem interesse nenhum em transcender o atual estado de coisas. Coutinho desconsidera assim, uma série de condições objetivas de correlação de forças que estabelecem as fronteiras das práticas politicas possiveis. Não se quer afirmar aqui que os governos Lula não reforçaram o status hegemônico da pequena política, mas tal hegemonia parece responder a uma conjuntura mais ampla e, também, à própria estrutura do Estado capitalista que, dificilmente, vai absorver e fomentar as grandes disputas que envolvem, inclusive, a sua desaparição. Antes pelo contrário, é próprio do Estado absorver e fomentar as disputas administrativas e desacreditar e, em certos casos, criminalizar, as ambições e movimentações da grande politica. 
Desconsiderando as especificidades expostas acima, pode-se resumir a tese do governo de conciliação de classes do seguinte modo. Num quadro de crise dos governos neoliberais, o Estado brasileiro incorporou os quadros dirigentes dos movimentos sindical e popular com o intuito de apassivá-los pela operação de um pacto policlassista, garantindo, assim, a reprodução da dominação burguesa e a manutenção das instituições da República.

Além das críticas expostas a cada uma das variantes da tese da conciliação observa-se como crítica geral à unidade dessa tese a dificuldade de distinguir especificidades que justifiquem a relevância científica de tal caracterização, afinal, quais os governos não conciliam e não pactuam classes? (MARINGONI, 2017; MARTUSCELLI, 2018). Como observa Martuscelli (2018), a hipótese da conciliação de classes tem um caráter mais destacado de denúncia política à postura recuada do governo Lula em relação ao que se esperava dele do que, de fato, um caráter de análise pormenorizada das movimentações das diferentes classes e frações em sua relação com o Estado e o governo.

A última perspectiva a ser observada aqui se constitui como uma das mais celebradas teses sobre o período Lula, trata-se da leitura que identifica o fenômeno do lulismo como sendo um bonapartismo. O principal formulador dessa perspectiva é o cientista político André Singer (2012), para quem o lulismo constitui um fenômeno nascido de um realinhamento eleitoral ocorrido nas eleições presidenciais de 2006.

De acordo com Singer, o referido processo eleitoral marcou um afastamento significativo dos setores da classe média do candidato do PT, ao passo que, de maneira inédita, o candidato petista teria logrado o apoio massivo do subproletariado, uma massa numericamente representativa de trabalhadores precarizados, subempregados e empobrecidos sem condições de organizar-se como força política autônoma, mas que, pelo seu tamanho, tem condições de decidir os resultados dos pleitos eleitorais. Essa classe, ao aspirar amenizar sua situação de pobreza, caracterizar-se-ia por uma ideologia política de tipo conservador, pois, almejaria integrar-se no proletariado existente, ou seja, nas relações sociais de produção que predominam na formação social brasileira. Desse modo, recusariam os discursos radicais que ameaçam a estabilidade política e que, pela sua 
concepção de classe, prejudicariam ou retardariam o seu acesso aos direitos trabalhistas, ao crédito, ao consumo, etc.

O governo Lula, ao aplicar o programa do subproletariado, teria capturado essa massa eleitoral, conquistando, com isso, uma autonomia em relação às classes fundamentais do capitalismo brasileiro e seus respectivos programas econômicos e políticos. Dessa maneira, a partir de 2007, o segundo governo Lula teria sido marcado por uma postura ziguezagueante, constituída pela arbitragem entre aquelas classes fundamentais, o que teria causado, inclusive, uma aproximação do capital industrial com o proletariado, forjando uma coalização produtivista que fizesse frente à chamada coalizão rentista encabeçada pelo capital financeiro.

O programa do subproletariado aplicado pelo governo poderia ser caracterizado como um reformismo fraco na medida em que visava à diminuição da extrema pobreza e das desigualdades regionais pela integração dessa massa "excluída" no proletariado tradicional. Por essa via não necessariamente tocar-se-ia na propriedade e na renda dos grandes capitalistas, apenas expandir-se-ia as condições de empregabilidade e consumo. A consequência social desse processo de integração seria a criação de condições favoráveis à luta do proletariado tradicional que não mais estaria ameaçado pela pressão da miséria e do desemprego. A classe que seria desfavorecida pelo desparecimento do subproletariado não seria a dos grandes capitalistas, mas a classe média que, pela melhoria das condições materiais de existência do subproletariado - cada vez menor - observaria uma elevação dos custos de reprodução da força de trabalho vinculados aos serviços tipicamente consumidos por ela.

A leitura de conjuntura estabelecida por Singer é muito bem fundamentada e justificada, sendo sua hipótese do realinhamento eleitoral ocorrido em 2006 confirmada por dados empíricos consistentes. Entretanto, embora seja uma perspectiva interessante, essa carrega consigo algumas imprecisões conceituais que desafiam a validade da caracterização sobre o período, a de que se trataria de um governo de arbitragem ${ }^{5}$.

\footnotetext{
5 A crítica centra-se aqui, principalmente, à aplicação, para o período Lula, da noção de "governo de arbitragem", o qual seria caracterizado por um grau tão acentuado de autonomia em relação às classes dominantes que o programa aplicado teria uma origem estranha a essas classes. Outra crítica possível é aquela que se volta à definição do conceito de bonapartismo, a qual pode ser encontrada em Boito Jr
} 
Uma primeira crítica que vai de encontro à perspectiva da arbitragem diz respeito à contradição na definição de subproletariado e a função política que essa fração de classe teria desempenhado na referida conjuntura. Se uma das características substanciais daquela classe é a incapacidade de organização, ou seja, a sua ausência na cena política como fração autônoma, poderia essa mesma classe estabelecer um programa politico e, ainda por cima, ter condições de arbitrar sobre as classes fundamentais? (BOITO Jr, 2018).

Vale ressaltar que a arbitragem que caracterizou a postura do governo de Luís Bonaparte estabeleceu-se com um golpe de Estado contra as recémnascidas instituições republicanas, as quais não lograram organizar a hegemonia de uma das frações das classes dominantes sobre as outras (MARX, 2008). Desse modo, a arbitragem instituiu-se contra a anarquia institucional e pela consolidação da hegemonia de toda a burguesia como classe politicamente dominante a despeito dos interesses particulares e contraditórios de cada fração. O normal funcionamento das instituições republicanas (burguesas) durante o período Lula e, sobretudo, o respeito às eleições periódicas e o seus resultados, com ênfase no parlamento, advoga contra a tese da arbitragem, pois, não constitui um indicativo de crise de hegemonia no interior do bloco no poder que justifique um governo de tipo bonapartista, o qual asseguraria a hegemonia de toda a burguesia pela supressão de suas instituições típicas.

Outra questão importante é a desconsideração de como se distribui/concentra poder nas formações sociais (MARTUSCELI, 2018; BOITO Jr, 2018). Para Singer (2012) o poder parece ser uma questão meramente eleitoral e que, além disso, se suspende no processo eleitoral para voltar a fazer parte da equação após a resolução do pleito. Com tal convicção nos processos eleitorais, Singer acaba caindo no mesmo erro de Sader, que é o de reduzir a hegemonia política à hegemonia eleitoral. A própria dinâmica dos processos políticos tem ratificado que hegemonia eleitoral possui um significado importante, mas não constitui o seu fator principal. O processo acelerado de decomposição do governo petista a partir do momento em que 
setores importantes da burguesia interna desembarcaram do governo mostra que a luta eleitoral não só já se dá em condições de desequilíbrio, como vencêla não é sinônimo de governar, pois a hegemonia no interior do bloco no poder cumpre um papel determinante. Dessa maneira, se a questão do poder estivesse reduzida à questão eleitoral, tal como na leitura de Singer - em que do peso eleitoral do subproletariado deriva-se o controle sobre o aparelho de Estado e a aplicação do seu programa - o estabelecimento de governos burgueses seria, em consequência da sua insignificância demográfica, inviável.

\section{Alternativas teóricas para a análise de conjuntura}

$\mathrm{Na}$ seção anterior foi apresentado um panorama geral das diferentes caracterizações sobre os governos Lula destacando-se as principais limitações de cada uma delas. Observando o conjunto de tais limitações e negligenciando àquelas que, como já indicado, não tem confirmação empírica, ressaltam-se dois problemas teóricos de fundo nas teorias abordadas.

O primeiro dos problemas é o fetichismo de Estado, o qual consiste em atribuir ao aparelho de Estado a qualidade de fonte autônoma de poder, como se esse não respondesse a uma correlação entre forças sociais diversas (BOITO Jr, 2018, p. 126). Essa insuficiência teórica que oculta a dinâmica dos processos políticos aparece em Sader de modo explícito quando esse reduz a explicação da dinâmica política do período às qualidades do chefe do executivo. Em Singer, a presença do fetichismo do Estado se dá de modo implícito, pois, embora evoque a dinâmica das classes como chave explicativa, o autor indica a importância eleitoral do subproletariado como elemento suficiente para justificar o processo de arbitragem sobre as classes fundamentais, como se o poder politico emanasse única e exclusivamente de vitórias eleitorais. Tal insuficiência teórica se vence por meio de uma teoria da conjuntura.

O segundo problema de fundo, presente nas diferentes versões da tese da conciliação de classes, refere-se à combinação de dois elementos: o economicismo e o voluntarismo. O economicismo refere-se à relevância explicativa transcendental atribuída à contradição capital-trabalho, cuja dinâmica determinaria toda e qualquer conjuntura, desse modo, o governo 
Lula emergiria como sendo resultado de uma estratégia política de toda a burguesia voltada para conter a ascensão do proletariado. O elemento voluntarista manifesta-se pela compreensão de que tal contradição não teria se desenvolvido com vantagem para o polo do trabalho devido à postura das direções partidárias que optaram pelo caminho da conciliação, como se a própria estrutura social objetiva não oferecesse resistências. Essa perspectiva aparece na tradição trotskista sob a fórmula da "burocratização das direções" e no léxico gramsciano como "transformismo de grupos radicais inteiros". Tais lacunas teóricas podem ser reconsideradas de modo mais satisfatório a partir das teorias do bloco no poder e das frações burguesas.

\section{a) O fetichismo de Estado e a teoria da análise de conjuntura}

O conceito de conjuntura refere-se a um tempo num espaço, esse espaço é o objeto concreto-real do materialismo histórico, as formações sociais, definidas como unidades singulares que se distinguem pela combinação específica dos modos de produção e suas instâncias constitutivas. Em outras construções teóricas é o que comumente se nomeia pelo impreciso termo de "sociedade". No materialismo histórico o desígnio "sociedade" é substituído pelo conceito de formação social, pois aquele remete a um plano monodimensional, que toma como premissa teórica verdadeira os efeitos ideológicos produzidos pela estrutura jurídico-política do Estado: o efeito de isolamento, que equaliza os agentes que ocupam posições desiguais na produção como sujeitos de direito; e o efeito de representação da unidade, que reúne os agentes equalizados pelo efeito de isolamento na condição de cidadãos membros de uma mesma comunidade, um Estado-nacional, portanto, uma "sociedade".

A formação social, por sua vez, remete a amarração específica dos modos de produção levando em consideração a amarração específica de suas instâncias e dos elementos que as caracterizam. Dessa maneira é possivel tomar a formação social como "uma rica totalidade de determinações e relações diversas" (MARX, 2008, p. 258), que os conceitos vazios encerrados em modelos planos, tais como os de atores e agentes, são incapazes de abarcar.

Com a formação social descobrem-se então uma variedade de agrupamentos sociais especificados pela combinação de múltiplos 
determinantes, tais como: a) as classes sociais, que são agrupamentos caracterizados pela presença pertinente nos níveis politico e ideológico a partir da posição ocupada nas relações de produção; b) as frações de classe que, nos marcos da sua unidade geral de classe, emergem no âmbito da disputa particular no político; c) as categorias sociais, ou seja, agrupamentos que se diferenciam determinantemente pela relação estabelecida em outros níveis que não o econômico, tal como a burocracia, no caso da sua posição privilegiada no político; ou os intelectuais, no caso da sua posição privilegiada no ideológico; e d) as camadas sociais, grupos constituídos pela combinação específica de determinados modos de produção em uma determinada formação social, como o caso da aristocracia operária.

Todos esses grupos podem, além disso, também ser considerados de acordo com o papel que desempenham nas lutas políticas. Assim aparecem as classes dominantes, caracterizadas por serem organizadas e representadas no Estado constituído. Aparece a classe hegemônica, que é o vértice de unidade entre as classes dominantes na constituição do bloco no poder. Aparecem as classes-apoio, que são incapazes de organizar-se de modo autônomo e, mobilizadas desde fora por meio das próprias estruturas do Estado, fortalecem passivamente projetos de outras classes. Aparecem as classes reinantes, aquelas cujos partidos ocupam lugares privilegiados na cena politica. Aparecem as classes detentoras, àquelas onde são recrutados os politicos profissionais e a burocracia. Enfim, uma série de outras determinações especificadas pela própria tipicidade como os modos de produção se combinam em cada formação social (POULANTZAS, 1977).

O conceito de conjuntura, por sua vez, remete à presença, à vigência e à emergência da formação social num dado momento. Nas palavras de Poulantzas é o "lugar privilegiado onde se reflete a individualidade histórica sempre singular de uma formação, é a situação concreta da luta política de classe" (POULANTZAS, 1977, p. 91). Tomando por referência a famosa sentença na qual Marx declara que os "homens fazem a sua própria história, mas não a fazem como querem, não a fazem sob circunstâncias de sua escolha e sim sob aquelas com que se defrontam diretamente” (MARX, 2008, p. 19), pode-se caracterizar a conjuntura, justamente, como o quadro de circunstâncias com o qual os homens se defrontam diretamente, assim, a 
história invariavelmente só pode ser vivida nas conjunturas e transformada por meio das conjunturas.

Para a operacionalização satisfatória do conceito de conjuntura faz-se necessário desagregá-lo em seus elementos mais simples. O primeiro desses elementos é o acontecimento. De acordo com Herbert de Souza, ao considerar uma conjuntura é necessário distinguir os fatos dos acontecimentos, pois:

existem ocorrências que se constituem em acontecimentos tais como greves gerais, eleições presidenciais (principalmente se são diretas...), golpes militares, catástrofes, descobertas científicas de grande alcance. Estas ocorrências por sua dimensão e seus efeitos afetam o destino e a vida de milhões de pessoas, da sociedade em seu conjunto (SOUZA, 1984, p. 10).

A partir dessa distinção entre fato e acontecimento, define-se o acontecimento como qualquer fato cujas repercussões sejam pertinentes para o modo como se reproduz uma formação social. Portanto, uma conjuntura é um ciclo de acontecimentos que expressam uma tendência no modo como se reproduz uma formação social, atribuindo, assim, sentido a um período dessa formação.

Tomando por consideração os acontecimentos políticos, conclui-se que esses não são capazes de produzir-se senão por meio da ação de forças sociais politicamente ativas. Portanto, a análise da conjuntura envolve a definição do conceito de forças sociais, cuja correlação de forças produz a tendência dos acontecimentos numa conjuntura determinada. As forças sociais são entendidas, assim, como diferentes conjuntos compostos pelos elementos politicamente ativos das diferentes camadas, categorias, classes e frações que constituem uma formação social.

Se as forças sociais reúnem-se e distinguem-se por serem politicamente ativas, isto é, pela ação política, isto é, pela prática política, cabe definir esse tipo de prática. Define-se, então, como prática política aquela prática que tem como matéria-prima a conjuntura e por produto a influência na ação do Estado, estrutura jurídico-política definida pela função de organizar a dominação de uma classe sobre as outras. A prática política é o que especifica e reúne os elementos dos diferentes agrupamentos sociais como força social. As forças sociais distinguem-se entre si pelos objetivos dessa prática politica, ou seja, pelo programa politico que as mobilizam. Assim, uma 
força social pode ser definida como uma unidade heterogênea de elementos politicamente ativos de diferentes classes, frações, camadas e categorias mobilizadas por um programa politico.

Ao considerar as forças sociais é, portanto, fundamental fazer duas observações, a composição das forças sociais, ou seja, os agrupamentos sociais mobilizados; e a disposição desses agrupamentos, ou seja, a função que cumprem no modo como se agrupam. Na primeira observação reaparecem os conceitos de classe, fração, categoria e camada. Na segunda, aparecem os conceitos de: aliança política, que reúne as forças sociais organizadas de modo independente, estabelecendo um programa mínimo comum (BOITO Jr, 2012); frente política, que se diferencia da aliança por não envolver um acordo explícito entre as forças sociais envolvidas, mas uma convergência em que algumas das forças sociais podem ser instrumentalizadas sem mesmo saber que participam da frente (BOITO Jr, 2012); força dirigente, que define os objetivos estratégicos da frente; força principal, que é determinante para realização dos objetivos estabelecidos; e classe-apoio, já definida mais acima.

Até aqui a anatomia do conceito de conjuntura revelou os seus três elementos constitutivos: a) os acontecimentos; b) a correlação de forças sociais que produz os acontecimentos; e c) a correlação de classes, frações, camadas e categorias no interior das forças sociais, definindo, com isso, tanto o objetivo da força social, como os meios que essa força tem a disposição. Essa complexa amarração entre os diferentes tipos de elementos da conjuntura não é autoevidente, mas antes uma estrutura subterrânea cuja dinâmica manifestase como fenômeno na cena política, onde os homens, supostamente destituídos de interesses e movidos exclusivamente por convicções e valores, constituem correntes de opinião e, no sentido de realizar suas convicções acerca do interesse geral da nação e do povo, debatem ideias tentando convencer uns aos outros a votar de determinado modo nos processos deliberativos. Essa concepção idílica dos processos políticos que produzem os acontecimentos não constitui, para o materialismo histórico, uma realidade última, mas uma "realidade superficial como um véu que desempenha uma função particular, qual seja, a função de ocultar a realidade profunda" (BOITO Jr, 2007, p. 137). Portanto, 
a análise política marxista das sociedades capitalistas só começa quando, e somente quando, o analista evidencia os laços complexos que unem a cena política aos interesses econômicos e aos conflitos de classe. Praticar análise política designando os agentes presentes na cena política pelos nomes e objetivos que eles próprios se dão é permanecer na superficie enganosa do fenômeno (BOITO Jr, p. 140, 2007).

Dentre os grandes trabalhos de análise politica que pretenderam desvendar a dinâmica subjacente da cena politica, sobressaem-se os conhecidos textos históricos de Karl Marx, dentre os quais se destaca $O$ Dezoito do Brumário de Luís Bonaparte (MARX, 2008). Nesse texto o autor alemão propõe um exame da conjuntura de constituição, crise e dissolução da II República Francesa, cujo fim fora marcado pela ascensão de Luís Bonaparte ao poder e, a posterior, proclamação do II Império. Embora Marx não tenha deixado um instrumental sistematizado para uma análise de conjuntura que transcenda os limites da cena politica, desses textos é possivel derivar indicações gerais que aparecem ali em estado prático. O professor Armando Boito Jr (2007), numa espécie de leitura sintomal6 do Dezoito do Brumário procura indicar os principais vínculos estabelecidos por Marx no processo de análise da referida conjuntura. Basicamente Boito indica que Marx identificou uma série de coerências em diferentes níveis de práticas, buscando vincular as classes, as frações e as camadas aos partidos e tendências e os seus grupos parlamentares. Os principais indicadores desses vínculos seriam as plataformas políticas defendidas pelos grupos parlamentares que, apresentando-as como interesse geral do povo francês, representavam efetivamente os interesses das diferentes camadas, frações e classes organizadas em forças sociais, representadas, por sua vez, pelos partidos e grupos parlamentares.

Nas considerações acerca do conceito de conjuntura observara-se que essa tem um meio de manifestação cuja característica principal é ocultar a estrutura e a dinâmica substantiva da própria conjuntura, anunciando a si (o meio de manifestação) como sendo a realidade última, autorreferente e dotada de vida própria, a cena política. O equívoco do fetichismo de Estado é tomar a

\footnotetext{
${ }^{6}$ Leitura sintomal refere-se a um procedimento de estudo aplicado por Althusser para ler as obras de Marx. Em suma, considera-se que os textos não propriamente teóricos carregam em estado aplicado uma teoria que pode ser desvendada por um tipo de leitura que compreenda o texto, justamente, como sintoma da teoria, que presente em estado prático não se encontra em estado teórico-sistemático. Ou seja, trata-se de uma leitura ativa e sistematizante.
} 
cena política como dinâmica única e determinante, desconsiderando a dinâmica das forças sociais que lhe dão vida. A teoria da conjuntura é a superação teórica dessa limitação, pois evidencia as relações estabelecidas entre os grupos sociais especificados na formação social.

\title{
b) Economicismo, voluntarismo, bloco no poder e as frações burguesas
}

$\mathrm{Na}$ tentativa de definir de modo um pouco mais preciso o conceito de conjuntura, esse foi definido no item anterior como "um ciclo de acontecimentos que expressa uma tendência no modo como se reproduz uma formação social, atribuindo, assim, sentido a um período dessa formação”. Essa definição, embora necessária, é insuficiente para uma operação apurada do conceito, pois, o mesmo precisa ser qualitativamente tipificado. Portanto, distingue-se o conceito de conjuntura em dois subtipos: as conjunturas de transição e as conjunturas de reprodução.

As conjunturas de transição remetem a periodos excepcionais de crise da dominância de um modo de produção no interior de uma formação social abrindo, assim, uma janela histórica pela qual se torna possivel transitar para dominância de um novo modo de produção. Como bem define Martuscelli, tais conjunturas constituem

\begin{abstract}
situações históricas marcadas pela não correspondência entre forças produtivas e relações de produção; pela defasagem entre as estruturas sociais; pela existência da luta de classes no sentido forte do termo, ou seja, no sentido de que as classes colocam-se em confronto pela preservação ou mudança da dominância de um determinado modo de produção; pela existência de uma crise política que se caracteriza como crise revolucionária e coloca como possibilidade histórica a substituição da velha classe dominante por uma nova - nesse caso, é o bloco no poder como um todo que se encontra em crise, o que abre espaço para a disputa pela hegemonia entre as forças sociais da antiga e da nova forma de sociabilidade. Em sintese, a crise revolucionária no capitalismo corresponde a um fenômeno histórico que faz com que os efeitos ideológicos das estruturas deixem de condicionar as práticas das classes sociais (MARTUSCELLI, 2018, p. 105).
\end{abstract}

Esse tipo de conjuntura excepcional é o teatro de operações da história, onde classes antagônicas travam as batalhas mais decisivas pela consolidação da sua hegemonia. São a conjunturas desse tipo que Marx, ao tratar da sucessão de largos períodos históricos, refere-se quando assevera que "as lutas de classes são o motor da história”. Vale salientar que, nesse caso, tanto 
o termo "luta de classes" quanto o termo "história" adquirem um significado restrito. Portanto, nem toda a luta politica pode ser considerada luta de classes e nem toda sucessão temporal de acontecimentos pode ser considerada história, trata-se, pontualmente, de conjunturas impares de desajuste nos processos de reprodução da dominância de um modo de produção em determinada formação social.

O outro tipo de conjuntura, consideravelmente mais trivial, são as chamadas conjunturas de reprodução. Em que não está em jogo a dominância de um modo de produção em determinada formação social, mas uma série de outras questões, tais como a distribuição do excedente, por exemplo. O tipo de conjuntura de

\begin{abstract}
reprodução social designa a situação histórica marcada pela correspondência entre forças produtivas e relações de produção, pelo condicionamento recíproco das estruturas sociais, pela existência de uma luta de classes no sentido fraco do termo - isto é, a luta de classes assume a feição de um conflito distributivo funcional à reprodução social, ou seja, ainda que haja mudanças nas relações no seio das classes dominantes e entre classes dominantes e dominadas, essas mudanças ocorrem sem colocar em risco a dominação de classe vigente. Nesse sentido, a disputa pela hegemonia política é uma disputa travada fundamentalmente entre as classes e frações dominantes e as crises politicas existem como crises positivas para as classes dominantes, o bloco no poder em vigor, não assumindo, assim, nenhum papel antissistêmico ou antiestrutural (MARTUSCELLI, 2018, p. 106).
\end{abstract}

Portanto, uma correta análise de conjuntura pressupõe observar a diferença entre os seus dois diferentes tipos, pois, somente dessa maneira o analista pode distinguir na dinâmica da luta política aquelas contradições que cumprem um papel explicativo principal e aquelas que, também fundamentais ao resultado final da equação, entram como elementos secundários. É nesse ponto que a hipótese da conciliação falha, pois, ao não distinguir as conjunturas de reprodução das conjunturas de transição, acaba essencializando como contradição principal um tipo de contradição que raramente assume tal protagonismo nas, mais frequentes, conjunturas de reprodução.

Nesses casos verifica-se uma verdadeira luta contra os fatos para a justificação das hipóteses, pois, mesmo que o proletariado não se imponha nas lutas politicas como força social determinante e que a dinâmica dos acontecimentos aponte para embates que envolvam outros interesses e 
classes, a análise continua voltada para a contradição que na conjuntura específica apresenta-se como secundária (o problema economicista). Por tal equivoco, classe-apoio passa cumprir o papel de classe dirigente; a pequenapolítica, que é típica de tais conjunturas, passa a ser resultado da escolha racional dos chefes (o problema voluntarista); e toda a dinâmica da cena política é justificada pela necessidade de apassivamento da classe operária, como se uma insurreição estivesse à vista.

Se a existência das classes politicamente dominantes é um consenso, há de se considerar, necessariamente, que essas classes se diferenciam das classes politicamente dominadas e que, nas conjunturas de reprodução dessa relação, as movimentações das classes dominantes tem uma maior relevância explicativa devido à relação privilegiada que essas mantêm com o aparelho de Estado. Desse modo, formula-se o conceito de bloco no poder, que expressa a unidade desigual das classes e frações dominantes em sua relação com o Estado. Ao contrário das conjunturas de transição, nas conjunturas de reprodução o foco de observação principal não pode ser a contradição capitaltrabalho, mas as contradições entre as classes e frações dominantes no interior do bloco no poder, pois, são essas contradições que são refletidas de modo principal e determinante nas dinâmicas estatais, sobredeterminando as outras contradições presentes nas formações sociais. Tal como adverte Décio Saes

\begin{abstract}
a situação revolucionária é um estado excepcional, e não corriqueiro, das coletividades cindidas em classes sociais antagônicas. Quando tal situação não se delineia, impõe-se que o cientista político volte sua atenção para outro tipo de ação de classe, distinto da ação revolucionária das classes exploradas: a ação das classes exploradoras, com vistas a participar, juntamente com os funcionários do Estado, do processo de implementação da política de Estado. Neste caso, o cientista político está observando a relação entre o corpo de funcionários e os membros da classe exploradora no âmbito específico do processo de definição/execução da política de Estado (SAES, 1993, p. 21).
\end{abstract}

Assim, entra como questão principal para análise das conjunturas de reprodução uma teoria sobre os conflitos internos das classes dominantes. Pois, mais do que o óbvio momento de unidade política pela manutenção da dominação sobre os subalternos, é fundamental observar as lutas internas pela direção da dominação, ou seja, pela direção do processo de reprodução 
das classes dominantes, as quais não se equivalem entre si. Nesse sentido é fundamental uma teoria sobre as contradições entre os diferentes setores das classes dominantes nas formações sociais capitalistas, uma teoria das frações burguesas.

Sobre os sistemas de fracionamento da burguesia, cabe destacar a multiplicidade de possibilidades, as quais podem ou não se efetivar como motores dinamizadores das lutas políticas. É nesse sentido que se faz necessário distinguir as frações puras, ou seja, agrupamentos das classes dominantes que compartilham determinadas posições objetivas; das frações autônomas, que de fato emergem como força social mobilizada e realizada, não apenas potenciais (FARIAS, 2009).

O primeiro sistema de fracionamento que aqui se destaca está relacionado com as funções do ciclo de reprodução do capital, cujo processo constitui-se por três momentos complementares e contraditórios (SAES, 2014). O primeiro momento corresponde à função monetária, que é o comércio de dinheiro realizado pelo capital bancário; o segundo momento corresponde à função produtiva, que se refere à produção de mercadorias, realizada pelo capital industrial; e o terceiro momento reporta-se à função mercantil, que diz respeito ao comércio das mercadorias, realizado pelo capital comercial. Salienta-se que o capital financeiro não se confunde com o capital bancário, sendo aquele definido pela fusão do capital industrial com o capital bancário sob a dominância de um deles, nesse sentido o capital financeiro pode emergir como fração autônoma sem perder de vista suas contradições internas ou pode ser atravessado desde fora por diferentes sistemas de fracionamento.

Um segundo sistema de fracionamento diz respeito à "burguesia do espaço nacional na sua relação com o capital estrangeiro" (FARIAS, 2009, p. 87). Tal sistema de fracionamento remonta três posturas básicas. A da burguesia compradora, que ocupa a posição de extrema integração e associação com o capital estrangeiro, constituindo-se como um representante interno dos interesses daquele capital ${ }^{7}$. A referida postura geralmente é

\footnotetext{
7 O termo compradora para designar essa postura de identificação com o capital internacional remonta a um período em que havia um entrecruzamento muito forte entre essa postura e as atividades econômicas vinculadas ao comércio de exportação e importação. Com o processo de reestruturação produtiva dos anos de 1970 e o desenvolvimento de novos processos de integração entre o capital periférico e imperialista o termo compradora pode ser substituído pelo de burguesia associada, que designa a mesma postura, porém não enclausura os portadores dessa conduta nas atividades
} 
assumida pelas frações do capital bancário e comercial vinculados à exportação e importação e raramente assumidas por capitais vinculados à indústria e a expansão do mercado interno. A postura que corresponde a uma antípoda da burguesia compradora é a da burguesia nacional, cuja organização tende a se realizar pelo entrecruzamento com frações vinculadas ao capital industrial e ao mercado interno, as quais desenvolvem uma conduta de contradição aberta com os interesses do capital estrangeiro. Entre os dois extremos localiza-se a burguesia interna, cuja postura é marcada pela ambiguidade em relação ao capital externo, pois, ao mesmo tempo que o seu desenvolvimento vincula-se ao desenvolvimento do capital externo, aquele se dá de modo contraditório, pois, a burguesia interna almeja melhorar as condições de competição e associação com aquele capital, pleiteando, assim, politicas que possibilitem a realização dessas ambições, sobretudo no que diz respeito a sua presença nos mercados estrangeiros. Do ponto de vista ideológico, é uma fração extremamente frágil, marcada por uma dinâmica pendular, a qual tende a inviabilizar a sua reprodução como classe hegemônica no interior do bloco no poder por um período alargado (MARTUSCELLI, 2018). De acordo com Martuscelli:

Dois fatores parecem, portanto, explicar o deslocamento das burguesias internas nos países de capitalismo dependente para a formação de uma frente politica com os interesses mais alinhados ao imperialismo: o medo da emergência de uma pujante burguesia de Estado e os resultados de uma política de natureza mais expansionista, que podem tornar a luta dos trabalhadores menos vulnerável nos conflitos distributivistas (MARTUSCELLI, 2018b, p. 69).

A burguesia de Estado referida na citação acima se vincula à distinção entre capital público e capital privado, podendo emergir como fração autônoma a partir de uma unificação ideológica específica entre um aparelho partidário, um corpo organizacional intermediário e o corpo técnicoadministrativo de empresas públicas que desempenham funções típicas do capital (MUTTI \& SEGGATTI, 1979). Nesse caso, “a burguesia de Estado deve manifestar uma estratégia econômica, uma linha de comportamentoprodutivo minimamente coerente e decifrável, mesmo que não

puramente mercantis, pois isso já não corresponde necessariamente à realidade, embora seja um entrecruzamento provável (MARTUSCELLI, 2009). 
necessariamente diferente daquela da burguesia privada" (MUTTI \& SEGGATTI, 1979, p. 20).

Entre outros tipos de fracionamentos possiveis podem ser destacados, ainda, os seguintes, o fracionamento regional, vinculado à origem central ou periférica do capital no território nacional; o fracionamento por posição ocupada no mercado, ou seja, se constitui capital monopolista ou não; e o fracionamento de escala do capital, que pode ser pequeno, médio ou grande. Desse modo, verifica-se que os diferentes sistemas de fracionamento se constituem com possibilidades diversas de combinação que podem ou não se realizar como fração autônoma. A constatação da existência dessas frações deve ser feita sempre se levando em consideração o caráter singular das conjunturas. Portanto, sendo as possibilidades de fracionamento diversas, cabe ao investigador, partindo das diversas possibilidades e formulações, identificar na conjuntura em questão aquela contradição que assume o caráter de contradição principal reunindo e arrastando consigo uma série de contradições secundárias na disputa pela hegemonia do bloco no poder cujo reflexo pode ser percebido nas políticas aplicadas ou negligenciadas pelo Estado.

No que tange à relação entre o bloco no poder com os aparelhos de Estado destaca-se que tal relação pode se dar pela presença direta ou não direta dos membros das classes e frações dominantes nos aparelhos estatais. A ocupação desses aparelhos por membros exógenos às classes dominantes tende a indicar um maior grau de autonomia relativa do Estado perante os interesses específicos de uma fração aumentando, com isso, a probabilidade "de o aparelho de Estado conceder beneficios às classes e frações subordinadas, a fim de obter a legitimação da ordem” (FARIAS, 2009, p. 94). Ressalva-se, no entanto, que essa ausência aumenta a probabilidade e, portanto, não constitui uma determinação mecânica inexorável, pois, as instituições estatais podem estar ocupadas por membros oriundos de classes ou categorias sociais que, embora não participem do bloco no poder, sejam extremamente identificadas do ponto de vista ideológico com uma das frações dominantes.

\section{Teoria aplicada e o Brasil neodesenvolvimentistas}


Sobre as conjunturas recentes da formação social brasileira, um diagnóstico que aparece em autores de distintas tradições teóricas e atravessa um período de tempo bastante significativo é aquele que indica uma divisão no interior da burguesia brasileira. O sociólogo Herbert de Souza (1984), por exemplo, ao tomar como objeto de análise a conjuntura de transição da ditadura militar ao regime democrático, define a classe dominante brasileira como estando dividida em duas correntes, "os liberais internacionalistas: setores dissidentes do PDS que ajudaram a constituir a transnacionalização da sociedade brasileira nos períodos Castelo, Geisel e Figueiredo" e os liberais nacional-reformistas: "lideranças de oposição ao regime anterior que expressam aspirações da classe média e das grandes massas marginalizadas" (SOUZA, 1984, p. 40). De acordo com o autor

As duas correntes têm em comum o objetivo de institucionalizar o regime liberal-democrático, que garanta o desenvolvimento do capitalismo no Brasil. Os liberais internacionalistas acentuam a identificação e compatibilidade entre o nosso desenvolvimento e a dinâmica do capitalismo mundial (a ordem mundial é benéfica à ordem nacional). Os liberais nacional-reformistas colocam ênfase na necessidade de atender mais à dinâmica do mercado interno e às necessidades de reformas estruturais que integrem no país real os milhões de marginalizados (a ordem mundial não é necessariamente benéfica à ordem nacional) (SOUZA, 1984, p. 40-41).

As duas correntes destacadas por Souza, embora com programas divergentes, aceitariam o princípio de alternância de poder pela disputa democrática, resolvendo por esses meios suas contradições. Essas diferenças programáticas se restringiriam, sobretudo, ao plano da política econômica. De um lado, os liberais internacionalistas defenderiam um programa composto pelos seguintes pontos: “a) pagar a divida externa; b) combater a inflação, reduzir os gastos públicos e combater a corrupção; c) desestatizar a economia; e d) acabar com todas as restrições a atuação do capital transnacional" (SOUZA, 1984, p. 42). Do outro lado, os liberais nacional-reformistas defenderiam um programa que passasse por

a) condicionar o pagamento da dívida externa à não aplicação de uma política recessiva sob imposição do FMI; b) combater a inflação sem achatar os salários; c) democratizar a gestão econômica sem sacrificar empresas públicas; e d) rever as estratégias de desenvolvimento de forma a dar prioridade a empresa nacional, ao mercado interno, à criação de empregos e ao combate à miséria (SOUZA, 1984, p. 42). 
O diagnóstico de Herbert de Souza na conjuntura de transição ao regime democrático é semelhante àquele estabelecido por Basílio Sallum Jr que, ao analisar a conjuntura dos anos de 1990, observa uma divisão entre os intelectuais formuladores da politica econômica do governo FHC. De um lado estaria a corrente denominada por ele de neoliberal doutrinária, que apostava na

estabilização rápida dos preços por meio das seguintes medidas complementares: a) manutenção do câmbio sobrevalorizado frente ao dólar e outras moedas, de forma a estabilizar os preços internos e pressioná-los para baixo pelo estímulo à concorrência derivada do barateamento das importações; b) preservação e, se possivel, ampliação, da "abertura comercial" para reforçar o papel do câmbio apreciado na redução dos preços das importações; c) o barateamento das divisas e a abertura comercial permitiriam a renovação rápida do parque industrial instalado e maior competitividade nas exportações; d) política de juros altos, tanto para atrair capital estrangeiro - que mantivesse um bom nivel de reservas cambiais e financiasse o déficit nas transações do Brasil com o exterior, como para reduzir o nível de atividade econômica interna - evitando assim que o crescimento das importações provocasse maior desequilibrio nas contas externas; e) realização de um ajuste fiscal progressivo, de médio prazo, baseado na recuperação da carga tributária, no controle progressivo de gastos públicos e em reformas estruturais (previdência, administrativa e tributária) que equilibrassem "em definitivo" as contas públicas; f) não oferecer estímulos diretos à atividades econômicas específicas, o que significa condenar as politicas industriais setoriais e, quando muito, permitir estímulos horizontais à atividade econômica - exportações, pequenas empresas, etc.; devendo o Estado concentrar-se na preservação da concorrência, através da regulação e fiscalização das atividades produtivas, principalmente dos serviços públicos (mas não estatais) (SALLUM Jr., 1999, p. 33).

Frente a esse neoliberalismo doutrinário, formara-se um grupo de intelectuais dissidentes, definidos por Sallum $\mathrm{Jr}$ como liberaldesenvolvimentistas, os quais resgatariam o antigo desenvolvimentismo, agora, sob a supremacia neoliberal, em que "também dá-se prioridade à estabilização monetária, mas a urgência com que ela é perseguida aparece condicionada aos efeitos potenciais destrutivos que as politicas antiinflacionárias ocasionarão no sistema produtivo" (SALLUM Jr., 1999, p. 35).

Se Sallum Jr. buscou observar o processo de cisão ideológica entre grupos de intelectuais dirigentes na conjuntura neoliberal dos anos de 1990, esse processo também foi observado, na mesma conjuntura, por Boschi e Diniz, entre setores do empresariado (BOSCHI e DINIZ, 2003). De acordo com os autores as divergências no empresariado se deveram a dois fatores, o primeiro de ordem econômica, vinculado à reestruturação produtiva, à 
abertura econômica e ao sacrífico do crescimento em nome da estabilidade; e o segundo, relativo à presença empresarial no âmbito político, pois, referia-se à desconsideração da estrutura de representação oficial corporativa por meio das federações empresariais. O governo FHC seria um governo excessivamente fechado em sua tecnocracia, excluindo dos processos de decisão uma parte do empresariado que estava historicamente acostumada a intervir por aqueles meios. Em suma, pode-se dizer que enquanto uma parte do empresariado integrou-se ao processo de abertura econômica mediante associação, compras e fusões e adequou-se aos novos mecanismos de influência, tais como o lobby; outra parte inseriu-se nesse processo de maneira diferenciada, observando a política neoliberal como uma ameaça, pois a

\begin{abstract}
abertura indiscriminada, juros altos e sobrevalorização da moeda teriam criado um ambiente muito favorável aos interesses financeiros em detrimento dos interesses industriais, privilegiando ainda o capital estrangeiro em detrimento do doméstico, o que também teve implicações negativas para o conjunto da economia ao gerar estagnação e altas taxas de desemprego (DINIZ e BOSCHI, 2003, p. 25).
\end{abstract}

Essa conjuntura crítica para determinados setores empresariais acirrou a cisão no interior da burguesia e de suas representações, possibilitando, assim, uma mudança progressiva na correlação entre as forças sociais em questão e, por conseguinte, na própria conjuntura. Tal modificação ensejou a superação da conjuntura neoliberal ortodoxa dos anos 1990 e inaugurou um novo ciclo de acontecimentos. Esse novo ciclo de acontecimentos começa a esboçar-se com a vitória da chapa encabeçada por Luiz Ignácio Lula da Silva e José Alencar nas eleições presidenciais de 2002, alcançando maturidade e vigor no segundo mandato, iniciado em 2007.

Ao realizar a análise dessa última conjuntura, a do segundo governo Lula, Armando Boito Jr (2012) mobiliza o instrumental teórico do materialismo histórico, sobretudo, o arcabouço poulantziano, cujos conceitos foram esboçados na seção anterior. Nesse sentido, diferentemente das análises já citadas, Boito pode definir mais precisamente no que de fato consistiu essa cisão no interior da burguesia brasileira que, de acordo com ele, constitui duas frações principais: a burguesia interna e a burguesia 
associada $^{8}$. O autor frisa que ambas as frações correspondem a grandes empresas com elevado grau de poder econômico, atuando não raramente como monopólios ou oligopólios, distinguindo-se, no entanto, pela postura frente ao capital estrangeiro, pois, enquanto a burguesia associada trabalharia na perspectiva de expandir a influência do capital externo no sentido de, com isso, ampliar também seus ganhos e influência, a grande burguesia interna manteria uma postura ambígua em relação ao capital externo, pois embora possa associar-se a ele, entende o mesmo como um concorrente, muitas vezes desproporcional, no mercado interno e nos mercados regionais onde possa vir a atuar. Desse modo a fração da burguesia interna procura, por meio da ação estatal, impor limites e controles sobre a expansão do capital externo. Armando Boito aponta que foi durante a conjuntura de implementação do neoliberalismo que essas frações se constituíram, pois a burguesia associada seria efeito dos

Grupos financeiros nacionais [que] beneficiaram-se com a politica de juros elevados e de liberdade para entrada e saída de capitais, empresas nacionais que se associaram a grupos estrangeiros para participar de leilões de empresas estatais, empresas comerciais ligadas à importação, os grupos empresariais das áreas de saúde e de educação, uma parte dos setores internacionalizados da indústria local (BOITO Jr., 2012, p. 75-76).

Por outro lado, a burguesia interna seria o efeito de outro setor do empresariado que encarou a abertura comercial como uma ameaça concorrencial no, antes quase exclusivo, mercado interno, sendo formada assim pelos

\begin{abstract}
grandes industriais brasileiros que junto com o agronegócio, formam o segmento mais importante da grande burguesia interna, [e que] mantinham uma relação contraditória com o programa neoliberal. Apoiavam, como toda a burguesia, a política social do neoliberalismo: desindexação dos salários, desregulamentação das relações de trabalho, redução e corte nos direitos sociais - nas áreas de saúde pública, de previdência pública e de educação. Porém, relutavam em aceitar ou mesmo se opunham a aspectos importantes da política econômica neoliberal: rejeitavam a política de abertura comercial, que ameaçava o mercado cativo que o desenvolvimentismo criara para a indústria local, e procuravam manter posições de força que tinham conquistado no capitalismo brasileiro e que eram ameaçadas pelas reformas neoliberais (BOITO Jr., 2012, p. 76).
\end{abstract}

\footnotetext{
8 Embora a definição sobre a postura da fração associada não mude na obra de Boito Jr (os artigos produzidos entre 2007 e 2017 reunidos na obra Reforma e Crise Política no Brasil), o autor usa de modo indiferenciado distintas nomenclaturas para caracterizar a mesma fração, tais como burguesia compradora, burguesia associada, burguesia integrada ou burguesia internacionalizada. Neste trabalho, para fins de unicidade conceitual, utilizar-se-á somente o termo burguesia associada.
} 
Nos governos de Fernando Henrique Cardoso, a fração hegemônica no interior do bloco no poder era, de acordo com o autor, a fração da burguesia associada, a qual se fazia representar na cena política pela aliança parlamentar entre o Partido da Social-Democracia Brasileira (PSDB) e o Partido da Frente Liberal (PFL), que logrou aplicar o programa neoliberal com êxito, a despeito das contrariedades impostas pela burguesia interna.

A burguesia interna, por seu turno, se unificaria pela concorrência contra o capital internacional e - com intuito de melhorar a sua posição no interior do bloco no poder e oferecer alguma resistência às medidas da fração neoliberalizante - teria se aproximado do movimento operário e popular em expansão, formando com ele uma frente política, a chamada frente neodesenvolvimentista, organizada na cena politica pela representação do Partido dos Trabalhadores (PT).

A arquitetura dessa frente estaria desenhada, naquele contexto conjuntural, do seguinte modo. A força dirigente seria a burguesia interna com o seu projeto neodesenvolvimentista, enquanto o movimento operário e popular estaria servindo como força principal. Esse descompasso entre força principal e força dirigente constituiu uma instabilidade na referida frente política, porém, mesmo assim, tal frente conseguiu impor uma série de medidas econômicas importantes para a burguesia interna, tais como

\begin{abstract}
A desativação a frio da Alca, a diplomacia e a política de comércio exterior visando à conquista de novos mercados no hemisfério sul, o fortalecimento das relações da economia brasileira com as economias sul-americanas, o congelamento do programa de privatização, o fortalecimento econômico e político das empresas estatais remanescentes e o novo papel do BNDES na formação de poderosas empresas brasileiras nos mais diferentes segmentos da economia (BOITO Jr., 2012, p. 81).
\end{abstract}

O objetivo da frente dirigida pela burguesia interna seria, portanto, a aplicação do programa econômico neodesenvolvimentista, que tem como fundamento básico o fortalecimento dessa fração burguesa mediante a associação com o Estado. Entre os pontos fundamentais desse programa destacam-se as politicas de ativação da demanda interna, o financiamento público de grandes empresas nacionais e de grandes obras de infraestrutura, uma política externa de apoio à expansão do capital nacional e medidas 
anticíclicas para contenção ou retardamento de crises (BOITO Jr, 2018). O referido programa não ambiciona a superação do modelo neoliberal, trata-se de "um conjunto de medidas que configuram uma estratégia de desenvolvimento capitalista mais ou menos coerente" (BOITO Jr, 2018, p. 265) que se desenvolve nos marcos de uma configuração mais ampla, estável e duradoura, o modelo econômico neoliberal.

Desde sua formação, a frente neodesenvolvimentista apresentava destacados pontos de fissura, tanto no interior da própria burguesia interna como entre a burguesia interna e o movimento operário e popular. Três seriam as contradições que oporiam os setores da burguesia interna. A primeira seria a contradição entre a grande indústria e o sistema bancário nacional, pois embora ambos se unifiquem em torno do protecionismo frente ao capital estrangeiro, entram em contradição em relação "a taxa básica de juros elevada, que aumenta o gasto público, dificultando a expansão e melhoria dos serviços de infraestrutura"; e a "liberdade dos bancos para fixarem o spread bancário, aumentando os custos do tomador de empréstimo" (BOITO Jr, 2012, p.100). Até aquele momento a medida governamental que servia como "o algodão entre os cristais" era o aumento do orçamento do BNDES e a "multiplicação dos programas de crédito subsidiado para a grande indústria e para o agronegócio" (BOITO Jr, 2012, p. 100). A segunda contradição se referiria à relação da grande indústria com o agronegócio, pois o objetivo fundamental deste último setor consistiria na facilitação da entrada dos seus produtos nos mercados dos EUA e da Europa, os quais exigem como contrapartida, a abertura do mercado interno aos manufaturados estrangeiros, o que contraria os interesses dos industriais. A terceira das contradições, por fim, seria a contradição entre capital público e capital privado. Ou seja, até que ponto o Estado deveria fortalecer e estender a atuação de empresas públicas nacionais ou apostar na construção de grandes empresas privadas.

Para além dessas três contradições principais no seio da burguesia interna, Boito menciona duas grandes contradições entre a burguesia interna e o movimento operário- popular que comprometem a estabilidade da frente politica. A primeira dessas contradições envolve um posicionamento referente ao gasto público, pois, de acordo com o autor 
A grande burguesia interna reluta em aceitar as pequenas concessões que o Governo Lula exige dela, para que seja possível manter a própria frente. Os grandes empresários querem: juros mais baixos, investimento estatal em infraestrutura, proteção alfandegária, BNDES a seu serviço, diplomacia empresarial e outras benesses, mas rejeitam a contratação de novos funcionários, reajustes para o funcionalismo, reajuste do salário mínimo, o gasto da previdência, etc. (BOITO Jr, 2012, p. 102).

A questão agrária seria o outro ponto de conflito, pois não seria possível para o governo manter boa relação política com o agronegócio e fazer uma reforma agrária ampla. A medida governamental para atenuar essa contradição foi a expansão do crédito para agricultura familiar, ou seja, para os camponeses com terra, ignorando uma outra base do movimento camponês, a qual é formada por aqueles que ainda não foram assentados, os camponeses mais pobres.

A análise de Armando Boito Jr sobre a conjuntura do segundo governo Lula é aquela que sistematiza teoricamente as impressões acerca do fenômeno de cisão no interior da burguesia brasileira, que em Herbert de Souza aparecia sob o impreciso termo de "correntes"; que em Sallum Jr aparece apenas como discordância teórica entre os intelectuais do governo FHC; e em Diniz e Boschi como setores do empresariado mais ou menos satisfeitos. Com a mobilização do aparato conceitual do materialismo histórico Boito Jr pode transpassar a cena politica, identificando as forças sociais ocultadas pelas siglas partidárias, sua composição e o seu modo de articulação.

Passando então para o quadro conjuntural de constituição do fracionamento principal que conformou a burguesia brasileira naquele período considera-se que a burguesia interna constituiu-se ideologicamente por um programa neodesenvolvimentista; cujo vetor político principal fora a frente neodesenvolvimentista, representada na cena política pelo Partido dos Trabalhadores; que organizava, unificava e representava os interesses desses setores empresariais que mantinham uma relação ambígua com a livre presença do capital externo no país. A fração burguesa associada, por sua vez, constituiu-se ideologicamente por um programa neoliberal ortodoxo; tendo sua presença organizada na cena política por meio da aliança parlamentar PSDB-DEM, que representa e organiza aqueles setores do empresariado que percebem como favorável aos seus próprios interesses a presença sem 
restrições do capital externo. De um lado a burguesia interna dirigia na referida conjuntura as forças sociais neodesenvolvimentistas, organizadas sob a forma de frente politica, na qual a força principal constituía-se pela classe trabalhadora organizada e o conjunto de outros setores populares. Essa frente teria ainda o apoio dos trabalhadores da massa marginal (proletariado pauperizado e precarizado) cujo consentimento organizava-se pela relação de tipo populista estabelecida, sobretudo, com o chefe do executivo, o Presidente Lula. A burguesia associada, por seu turno, dirigia as forças sociais neoliberais, organizadas, sobretudo, pela aliança parlamentar PSDB-DEM. Isolada do ponto de vista social as forças neoliberais marcam presença, no entanto, em centros de poder decisivos, tais como as instituições financeiras, setores decisivos da burocracia, como o judiciário, e os principais aparelhos de comunicação de massa, pelos quais se amplificavam o discurso de oposição das camadas superiores da classe-média. Essa classe é mobilizada pelo reforço obsessivo da ideologia da corrupção (BOITO Jr, 2017) que, além de atingir a burguesia interna (caracterizada pela associação Capital-Estado), serve como um instrumento típico e específico para mobilização daquela classe (a classe média), pois

A classe social que mantém uma relação univoca e preferencial com a bandeira da luta contra corrupção, percebida como mal absoluto da sociedade (capitalista), é a classe média. É o mal absoluto para o qual a classe média prescreve o remédio da reforma jurídica e moral. Tal postura provém da condição econômica e da ideologia meritocrática que caracterizam essa classe social. A crítica da classe média à organização social capitalista baseia-se na aspiração do reconhecimento do chamado critério do mérito individual (BOITO Jr., 2017, p. 17).

Soma-se a esse quadro o fato de o Presidente da República ter sido um torneiro mecânico sem instrução acadêmica, o que constitui um verdadeiro insulto para os portadores da ideologia meritocrática, os quais concebem o trabalho manual como o castigo merecido dos incompetentes.

Toda essa dinâmica pela hegemonia do bloco no poder atravessou o sistema de instituições estatais, sendo algumas dessas instituições capturadas pela burguesia associada e outras pela burguesia interna. Exemplos de instituições mobilizadas pelos interesses da burguesia associada seriam os setores estratégicos do Judiciário, da Polícia Federal e o Ministério Público Federal. A burguesia interna, por sua vez, teria capturado as grandes 
empresas estatais como Banco do Brasil, o BNDES e a Petrobrás. O modo como aquelas instituições foram mobilizadas contra essas últimas no processo de destituição da Presidente Dilma Rousseff são indicadores significativos dessa caracterização (BOITO Jr, 2018).

Nesse quadro, então, é possível indicar como contradição principal da conjuntura do segundo governo Lula o conflito distributivo de classes (BOITO Jr, 2018), que opõe pelo aspecto principal da contradição principal a burguesia interna e a burguesia associada; e como aspecto secundário as ambições por uma melhor repartição do excedente por parte do campo sindical e popular e dos trabalhadores da massa marginal, cuja polarização se desenvolvia também com as camadas intermediária e superior da classe média.

\section{Considerações finais}

A exposição do presente artigo partiu das diferentes caracterizações dos governos Lula destacando dessas os problemas teóricos que nelas se encontravam em estado aplicado. Tal procedimento se justifica pelo objetivo fundamental do artigo, qual seja: contribuir com a sistematização de uma teoria da análise de conjuntura. Portanto, priorizaram-se as apreciações críticas de cunho teórico capazes de transcender os limites singulares do objeto concreto-real em questão, a conjuntura dos governos Lula.

A partir de tal procedimento foram destacados dois problemas teóricos de fundo, o fetichismo de Estado e o economicismo-voluntarista. A superação do primeiro fora indicada pela teoria da conjuntura, a qual observa a produção dos acontecimentos políticos a partir da movimentação dos grupos diversos que compõem as diferentes formações sociais. A teoria do bloco no poder e das frações burguesas por seu turno propõe-se a superar o economicismo voluntarista, indicando que as movimentações dos grupos diversos não são equivalentes e não são transcendentes em sua importância, ou seja, a dinâmica política das classes dominantes tem um potencial explicativo diferenciado nas conjunturas de reprodução, pois essas mantém uma relação privilegiada com os aparelhos de Estado.

Por fim, apresentou-se uma apreciação do período Lula que leva em consideração o debate teórico anteriormente travado, sendo avaliada assim 
pelo presente autor como aquela que de modo mais rigoroso, no melhor sentido do termo, caracteriza o período. Tal observação sobre a precisão da proposição neodesenvolvimentista não se dá somente pelo indispensável rigor teórico já ressaltado, mas também pelo próprio desenrolar dos acontecimentos políticos que a cada dia corroboram com a já pretérita existência de um pacto instável entre agrupamentos diversos que a época neutralizara a aplicação do programa neoliberal ortodoxo, que hoje se apresenta sob a sua forma mais radical, cavalgando a besta neofascista.

O itinerário expositivo deste artigo partiu da abstração do problema teórico aplicado, passando pela correção dos equívocos teóricos indicados chegando à teoria corrigida em estado novamente aplicado. Salientando novamente o objetivo de contribuir com a sistematização de uma teoria da análise de conjuntura, o presente autor não propôs nenhuma novidade analítica em relação ao período. Nossa contribuição foi a de destacar, articular e confrontar criticamente alguns conceitos que aparecem aplicados ao objeto em questão, podendo, com isso, iluminar suas consistências e inconsistências mais gerais, oferecendo, também, uma silhueta das estruturas conceituais mobilizadas para investigação desta classe de objetos complexa e multideterminada, as conjunturas das formações sociais.

\section{Referências:}

ARCARY, Valério. Peculiaridades da história política do Brasil contemporâneo: notas para um balanço do ciclo de supremacia do PT e da CUT In: Lutas Sociais, PUC, SP: Volume 19/20 - $2^{\circ}$ semestre, 2008.

ARCARY, Valério. Dez anos de governos de coalização dirigidos pelo PT. In: Dossiê 10 anos de governos do PT. Blog Marxismo 21, 2013. https://marxismo21.org/10-anos-de-governos-do-pt-natureza-de-classes-eneoliberalismo/

BERRINGER. Tatiana. Bloco no poder e política externa nos governos FHC e LULA. Tese de doutorado apresentada junto ao Programa de Pós-Graduação em Ciência Política da UNICAMP, Campinas, 2014.

BOITO Jr, Armando. Estado, política e classes sociais: ensaios teóricos e históricos. São Paulo: Editora Unesp, 2007. 
BOITO Jr. Governo Lula: a nova burguesia nacional no poder. In: Politica e classes sociais no Brasil dos anos 2000, org. Armando Boito Jr e Andreia Galvão. São Paulo: Alameda, 2012.

BOITO Jr, Armando. A corrupção como ideologia. Critica Marxista, $\mathrm{n}^{\circ} 44$, 2017.

BOITO Jr. Armando. Reforma e crise politica no Brasil: Os conflitos de classe nos governos do PT. Campinas, SP: Editora da Unicamp / São Paulo, SP: Editora Unesp , 2018.

BOURDIEU, Pierre. Sobre o Estado: Cursos no Collège de France. (198992). 1Ed. - São Paulo: Companhia das Letras , 2014.

BRAGA, Ruy. Apresentação in: Hegemonia às avessas: economia, politica e cultura na era da servidão financeira / Francisco de Oliveira, Ruy Braga e Cibele Rizek, (orgs.). - São Paulo: Boitempo, 2010.

BRAGA, Ruy. A Politica do Precariado: do populismo à hegemonia lulista. São Paulo: Boitempo, 2012.

COGGIOLA, Oswaldo. 10 anos de governo do PT - Frente Popular. In: Dossiê 10 anos de governos do PT. Blog Marxismo 21, 2013. https:// marxismo21.org/10-anos-de-governos-do-pt-natureza-de-classes-eneoliberalismo/

COUTINHO, Carlos Nelson. A hegemonia da pequena política. in: Hegemonia às avessas: economia, politica e cultura na era da servidão financeira / Francisco de Oliveira, Ruy Braga e Cibele Rizek, (orgs.). - São Paulo: Boitempo, 2010.

DINIZ, Eli; BOSCHI, Renato. Empresariado e Estratégias de desenvolvimento, Revista Brasileira de Ciências Sociais, Vol. 18 nº. 52 junho/2003.

FARIAS, Francisco Pereira de. Frações burguesas e bloco no poder: uma reflexão a partir do trabalho de Nicos Poulantzas. In: Critica Marxista, $\mathrm{n}^{\circ} 28$, 2009.

KATZ, Claudio. Neoliberalismo, Neodesenvolvimentismo, Socialismo. São Paulo: Expressão Popular: Perseu Abramo, 2016.

MARINGONI, Gilberto. Ascensão e queda de uma utopia tropical. In: Cinco mil dias: o Brasil na era do lulismo. São Paulo: Boitempo/Fundação Lauro Campos, 2017.

MARTUSCELLI, Danilo. A burguesia mundial em questão. In: $3^{\circ}$ Encontro Nacional da Anpocs, 2009.

MARTUSCELLI, Danilo Enrico. Classes dominantes, politica e capitalismo contemporâneo. Florianópolis: Editoria Em Debate/UFSC, 2018. 
MARX, Karl. O Dezoito do Brumário de Luís Bonaparte. São Paulo: Editora Martin Claret, 2008.

MILIBAND, Ralph. O Estado na Sociedade Capitalista. Rio de Janeiro: Zahar Editores, 1972.

MUTTI, Antônio; SEGATTI, Paolo. A Burguesia de Estado: estruturas e funções da empresa pública. Rio de Janeiro: Zahar Editores, 1979.

OLIVEIRA, Francisco de. A hegemonia às avessas in: Hegemonia às avessas: economia, politica e cultura na era da servidão financeira / Francisco de Oliveira, Ruy Braga e Cibele Rizek, (orgs.). - São Paulo: Boitempo, 2010.

POUlAnTZAS, Nicos. Poder Politico e Classes Sociais. São Paulo: Martins Fontes, 1977.

SADER, Emir. A construção da hegemonia pós-neoliberal in: 10 anos de governos pós-neoliberais no Brasil: Lula e Dilma / Emir Sader (org.). - São Paulo, SP: Boitempo; Rio de Janeiro: FLACSO; Brasil, 2013.

SAES, Décio. A Formação do Estado Burguês no Brasil (1889 -1891). Rio de Janeiro: Paz e Terra, 1985.

SAES, Décio. As Frações da Classe Dominante no Capitalismo: uma reflexão teórica. In: Milton Pinheiro (org.) Ditadura o que resta da transição. São Paulo, Boitempo, 2014.

SAES, Décio. Democracia. São Paulo: Editora Ática, 1993.

SALLUM JR., Brasilio. O Brasil sob Cardoso: neoliberalismo e desenvolvimentismo. Tempo Social; Rev. Sociol. USP, S. Paulo, 11(2): 23-47, out. 1999.

SINGER, André Vitor. Os sentidos do lulismo: reforma gradual e pacto conservador. São Paulo: Companhia das Letras, 2010.

SOUZA, Herbert José. Como se faz análise de conjuntura. Petrópolis: Editora Vozes, 1984. 